\title{
Arsenate-Induced Neural Tube Defects Not Influenced by Constant Rate Administration of Folic Acid ${ }^{1}$
}

\author{
VERGIL H. FERM AND DAVID P. HANLON \\ Department of Anatomy, Dartmouth Medical School, Hanover, New Hampshire 03756
}

\begin{abstract}
Serious suggestions have been made that dietary supplementation with folic acid (FA) and perhaps other vitamins during pregnancy may reduce the incidence of neural tube defect (NTD) in human newborns. The purpose of these experiments was to evaluate the effect of continuous infusion of FA on the incidence of NTDs induced by arsenate. This teratogen induces NTDs in up to $\mathbf{9 0 \%}$ of golden hamster fetuses when administered acutely during critical stages of embryogenesis. FA was administered by subcutaneously implanted osmotic minipumps beginning on the 6th day of gestation, $48 \mathrm{~h}$ before an acutely administered dose of sodium arsenate. The protective effect of $\mathrm{FA}$ was examined at three teratogenic dose levels of arsenate: optimal, with $90 \%$ NTDs, intermediate, with $38 \%$ NTDs, and low, with $20 \%$ NTDs. Fetuses were recovered at day 13 of gestation and examined for NTDs and other malformations. Maternal red cell folate levels were determined on day $8,48 \mathrm{~h}$ after implantation of the pumps. The results show that the maternal red blood cell level of FA can be significantly increased within $48 \mathrm{~h}$ by chronic infusion to levels which are almost two times $\mathbf{( 5 5 0}$ $\mathrm{ng} / \mathrm{ml}$ ) control levels. There was no significant protection against arsenate-induced NTDs following FA supplementation at any of three levels of this teratogen. (Pediatr Res 20: 761-762, 1986)
\end{abstract}

Abbreviations

FA, folic acid

NTD, neural tube defect

OMP, osmotic minipump

Deficiencies of certain vitamins, including FA, have been implicated in the development of NTDs in human pregnancies (1). Clinical trials, using FA and vitamin supplementation as a means of reducing the incidence of NTDs in human pregnancies, are now underway. We have reported that implantation of OMP (Alzet, model 2001) containing FA (Folvite, Lederle Co.) does not prevent the NTDs induced either by maternal hyperthermia or alcohol ingestion in the hamster embryo (2). Trotz et al. (3) have reported preliminary data suggesting that folinic acid supplementation by the osmotic minipump in the mouse decreased exencephaly caused by valproic acid (3). This report presents

Received January 6, 1986; accepted March 25, 1986.

Address for correspondence Vergil H. Ferm, M.D., Ph.D., Department of Anatomy, Dartmouth Medical School, Hanover, NH 03756.

This project has been financed in part with Federal funds from the Environmental Protection Agency under Grant R810078.

${ }^{1}$ The contents do not necessarily reflect the views and policies of the Environmental Protection Agency nor does mention of trade names or commercial products constitute endorsement or recommendation for use. further evidence that FA supplementation during pregnancy does not reduce the incidence of NTDs produced by a potent central nervous system teratogen. Specifically, we show in the hamster model that the incidence of NTDs produced by acute exposure to arsenate is not reduced by continuous dosing with FA prior or during the critical stages of embryogenesis.

\section{MATERIALS AND METHODS}

Timed pregnant hamsters (outbred strain of Lakeview Syrian hamsters) were obtained from the Charles River Co. One group was injected intraperitoneally on day 8 of gestation with a single dose of either $64.2,48.2$, or $40.1 \mu \mathrm{M} / \mathrm{kg}$ of sodium arsenate (Table 1). A second group of animals was implanted with two OMP on the 6th day of gestation, charged with FA (Folvite) at a concentration of $5 \mathrm{mg} / \mathrm{ml}$, in a manner described previously (2). Forty-eight hours later, on day 8 of gestation, they received the same dosage regimens of sodium arsenate as the animals in the first group. The presence in the mothers of one or two saline pumps or pumps containing FA alone has no teratogenic effect in the golden hamster (4). The animals were killed by $\mathrm{CO}_{2}$ inhalation on day 13 and examined for NTDs in a manner described previously (4) Embryonic resorption sites were also recorded.

A third group of animals was implanted with two pumps each filled with FA on day 6 of gestation. These animals were sacrificed on day 8 of gestation and cardiac blood obtained for folate assays. Blood samples were collected in glass tubes with EDTA as anticoagulant and frozen immediately after the hematocrit was determined. The red cell folate levels in these blood samples were then determined by radioimmunoassay using the Corning Folate Radioassay Kit. The same assay technique had been used previously for saline-filled pumps and single pumps filled with folate (2).

\section{RESULTS}

The data on the effect of folic acid supplementation of arsenicinduced malformations are summarized in Table 1 . The frequency of neural tube defects in litters from dams receiving arsenic alone was compared to that from dams receiving the same dose of arsenic along with FA. The statistical significance of the difference between these two groups was estimated by using the unpaired $t$ test on the Freeman-Tukey arcsin transformations of the proportion of fetuses affected per litter. The statistical sample size is thus the number of litters per group.

Hamsters maintained in this laboratory on regular lab food have unsupplemented maternal red cell folate levels ranging from $272-345 \mathrm{ng} / \mathrm{ml}($ mean $=301)$ on the 8 th day of gestation $(2)$. In that study, a single pump containing folic acid (Folvite) increased the maternal red cell level of folate in hamster blood to a range of $336-560 \mathrm{ng} / \mathrm{ml}$ with a mean level of 408 over a $48-\mathrm{h}$ period 
Table 1. Effect of continuous FA infusion on the incidence of neural tube defects at optimal, moderate, and low teratogenic levels of sodium arsenate

\begin{tabular}{|c|c|c|c|c|c|}
\hline Treatment & $\begin{array}{c}\text { No. of litters } \\
\text { with one or } \\
\text { more malformed } \\
\text { fetuses/ } \\
\text { total no. of litters }\end{array}$ & $\begin{array}{c}\text { Total No. of } \\
\text { implantation sites }\end{array}$ & $\begin{array}{c}\text { Total no. of } \\
\text { resorptions } \\
(\%)\end{array}$ & $\begin{array}{l}\text { No. of fetuses with one or } \\
\text { more neural } \\
\text { tube defects } \\
(\%)\end{array}$ & $\begin{array}{l}\text { Total no. of } \\
\text { normal fetuses } \\
(\%)\end{array}$ \\
\hline NaAs $64.2 \mu \mathrm{M} / \mathrm{kg}$-ip* & $9 / 9$ & 121 & $\begin{array}{c}33 \\
(27.2)\end{array}$ & $\begin{array}{c}84 \\
(95.4)\end{array}$ & $\begin{array}{c}4 \\
(4.5)\end{array}$ \\
\hline $\begin{array}{l}\text { NaAs } 64.2 \mu \mathrm{M} / \mathrm{kg} \text {-ip plus } \\
2 \text { Folvite pumps }\end{array}$ & $17 / 17$ & 223 & $\begin{array}{c}44 \\
(19.7)\end{array}$ & $\begin{array}{c}143 \\
(78.1)\end{array}$ & $\begin{array}{c}36 \\
(19.6)\end{array}$ \\
\hline $\mathrm{NaAs} 48.2 \mu \mathrm{M} / \mathrm{kg}-\mathrm{ip}$ & $8 / 11$ & 156 & $\begin{array}{c}8 \\
(5.1)\end{array}$ & $\begin{array}{c}56 \\
(37.8)\end{array}$ & $\begin{array}{c}92 \\
(62.1)\end{array}$ \\
\hline $\begin{array}{l}\text { NaAs } 48.2 \mu \mathrm{M} / \mathrm{kg} \text {-ip plus } \\
2 \text { Folvite pumps }\end{array}$ & $10 / 10$ & 139 & $\begin{array}{c}14 \\
(10.0)\end{array}$ & $\begin{array}{c}80 \\
(63.4)\end{array}$ & $\begin{array}{c}45 \\
(35.7)\end{array}$ \\
\hline $\mathrm{NaAs} 40.1 \mu \mathrm{M} / \mathrm{kg}-\mathrm{ip}$ & $8 / 10$ & 123 & $\begin{array}{c}7 \\
(5.6)\end{array}$ & $\begin{array}{c}24 \\
(20.5)\end{array}$ & $\begin{array}{c}92 \\
(78.6)\end{array}$ \\
\hline $\begin{array}{l}\text { NaAs } 40.1 \mu \mathrm{M} / \mathrm{kg} \text {-ip plus } \\
2 \text { Folvite pumps }\end{array}$ & $9 / 12$ & 163 & $\begin{array}{c}7 \\
(4.3)\end{array}$ & $\begin{array}{c}28 \\
(17.8)\end{array}$ & $\begin{array}{c}128 \\
(81.5)\end{array}$ \\
\hline
\end{tabular}

* Intraperitoneal.

Table 2. Maternal red cell folate levels $(\mathrm{ng} / \mathrm{ml})$ on day 8 of gestation in hamster

\begin{tabular}{cccc}
\hline Treatment & No. of mothers & Range & Mean \\
\hline Saline pumps only* & 7 & $270-340$ & 308 \\
FA-one pump* & 4 & $375-560$ & 400 \\
FA-two pumps & 6 & $467-592$ & 527 \\
\hline
\end{tabular}

* Reference 2 .

of exposure. In current experiments, with two pumps containing Folvite in place for the same amount of time, the mean maternal red cell folate level for six animals was $527 \mathrm{ng} / \mathrm{ml}$ with a range of 467-592 (Table 2). This level was maintained throughout the 24-h period of critical embryogenesis, and beyond, as demonstrated by our previous work (2).

\section{DISCUSSION}

The use of FA and/or multivitamin supplementation as a means of reducing human NTDs is currently receiving considerable attention and study (6). The use of OMPs as a method of delivery of FA assures the constancy of blood levels of this compound and precludes any problems associated with gastrointestinal absorption or variation in feeding habits.

In our experience with more than 15,000 litters of this species, the incidence of spontaneously occurring NTDs is less than $0.1 \%$. Day 8 of gestation in this species has been shown to be the most sensitive period for the induction of NTDs by arsenate (6). Arsenate, in the hamster model, is a very potent and consistent inducer of NTDs (6). It is important to note that the 8th day of gestation in the hamster corresponds to the 17- to 28-day period in human embryonic development (7). The neural tube in the hamster develops, folds, and closes completely in the 24-h period between days 8 and 9 of gestation. We have determined that following an acute bolus intraperitoneal injection of $64.2 \mu \mathrm{mol} /$ $\mathrm{kg}$ of sodium arsenate, the maternal blood reaches a level of 220 micromolar arsenic within $30 \mathrm{~min}$ and falls to a minimally teratogenic level (6.0 micromolar arsenic) in about $5 \mathrm{~h}(8)$. As shown in Table 1, even the effects of low-level teratogenic doses of arsenate are not mitigated by the presence of FA at levels which are above those in FA-supplemented human pregnancies (9).

While the primary etiologies of NTDs may be complex, there must be a final common morphogenetic pathway for these lesions, whatever their causes. NTDs produced by arsenate are morphologically identical to those NTDs caused by many other experimental agents, as well as those occurring spontaneously.

Continuous FA supplementation alone during the critical stages of embryogenesis does not reduce the incidence of NTDs associated with a potent NTD-inducer such as arsenate in this animal model system.

Acknowledgments. The authors thank Dr. William Layton for his statistical analysis of the data and Susan McLaughry for technical help.

\section{REFERENCES}

1. Smithells RW, Sheppard S, Schorah CJ 1976 Vitamin deficiencies and neural tube defects. Arch Dis Child 51:944-950

2. Graham JM, Ferm VH 1985 Heat and alcohol-induced neural tube defects: interactions with folate in a golden hamster model. Pediatr Res 19:247-251

3. Trotz M, Gansau CH, Nau H 1985 Effects of folic acid-deficient diet and folinic acid treatment on the embryotoxicity of valproic acid in the mouse. Teratology 32:35(abstr)

4. Ferm VH, Hanlon DP 1985 Constant rate exposure of pregnant hamsters to arsenate during early gestation. Environ Res 37:425-432

5. Seller MJ 1985 Periconceptual vitamin supplementation to prevent recurrence of neural tube defects. Lancet 1:1392-1393

6. Ferm VH, Saxon A, Smith BW 1971 The teratogenic profile of sodium arsenate in the golden hamster. Arch Environ Health 22:557-560

7. Ferm VH 1967 The use of the golden hamster in experimental teratology. Lab Animal Care 17:452-462

8. Hanlon DP, Ferm VH 1985 Concentration and chemical status of arsenic in the blood of pregnant hamsters during critical embryogenesis. II. Acute exposure. Environ Res (in press)

9. Schorah CJ, Wild J, Hartley R, Sheppard S, Smithells RW 1983 The effect of preconceptional supplementation on blood vitamin concentrations in women at recurrence risk for neural tube defect. Br J Nutr 49:203-211 